\title{
Effect Of Work Motivation On Teachers Of Junior High School Teachers In Muaro Jambi District
}

\author{
Yusdi Andra ${ }^{1}$, Denny Denmar ${ }^{2}$, Zuhri Saputra Hutabarat ${ }^{3}$ dan Apriani Tamarito $S^{4}$ \\ $\left\{{ }^{3}\right.$ zuhri.saputra.hutabarat@gmail.com $\}$ \\ 1,2,3,4 Jambi University, Indonesia
}

\begin{abstract}
The purpose of this study was to determine the effect of work motivation on the performance of teachers in public junior high schools in Muaro Jambi. This research uses descriptive quantitative method with survey techniques. The population in this study were all teachers of Muaro Jambi District Junior High School totaling 973 people. The sampling technique in this study was carried out by random sampling technique, and the level of trust equal to or more than .10.0.10, using representative intrapolation calculations to obtain a sample of 150 teachers. The variables in this study consist of one independent variable, namely work motivation (X) and one dependent variable, namely teacher performance $(\mathrm{Y})$. Data collection techniques are carried out using a closed questionnaire / questionnaire. The results of the data collection are then analyzed using a simple regression analysis test and the analysis of the coefficient of determination is aided by using the SPSS version 16.0 for Windows application program. The results of the study showed that work motivation had a significant and positive effect on the performance of teachers of public junior high schools in Muaro Jambi District with a contribution of $32.3 \%$, the remaining $67.7 \%$ of teacher performance in Muaro Jambi District Middle School was influenced by other factors not addressed in the study. this.
\end{abstract}

Keywords: Work Motivation, Teacher Performance

\section{Introduction}

Education is an important instrument that is needed in helping the process of developing and developing potential, talents, and interests effectively to achieve the expected educational goals (Ahmadi, 2014: 52). Education in Indonesia plays a role in improving the quality of life of the Indonesian people and helping to shape a dignified national civilization. Increasing the quality of quality human resources must be supported by qualified teachers. Quality teachers are also one of the human resources that strongly supports the implementation of educational institutions. Law Number 14 of 2005 concerning Teachers and Lecturers in chapter 1 of article 1 paragraph 1 explains that teachers are professional educators who have the main task in educating, teaching, guiding, training, directing, evaluating, and evaluating students in age education institutions formal education, basic education and secondary education.

A teacher who does not have high professionalism, the performance produced by the teacher will not be of high quality. According to Suprihatiningrum (2013: 39) teacher performance is the factor that determines the quality of learning. The performance of a teacher can be clearly seen through the learning he showed from the learning achievements of 
students. A good teacher's performance will be able to produce good student learning achievements (Supardi, 2014: 55).

According to Gibson (1987: 25) there are three factors that influence teacher performance, one factor that influences teacher performance is a psychological variable consisting of: perception, role, attitude, personality, motivation, and job satisfaction. In line with Gibson's opinion, Usman (2013: 276) explains that human performance is influenced by the function of motivation and ability. Some of these factors, which can affect aspects of the teacher's performance, one of which is the work motivation factor that is owned by each individual. With the motivation to work, it will certainly create the best performance. This is supported by the opinion of Wursanto (1989: 132) "... besides requiring personal abilities or skills, also requires sufficient motivation in a person, so that the work done can be very good." According to Usman (2013: 276) work motivation can interpreted as a desire or need that becomes someone's background so that he is motivated to work harder. If the teacher has a strong urge from within him or encouragement from outside himself, then the teacher will be compelled to do a good job. Giving work motivation to the teacher can be interpreted as moving the teacher to direct them to efforts that can achieve the stated goals. In the implementation of motivational learning plays both intrinsically both from within the individual and extrinsic from outside the individual. According to Wursanto (1989: 131) motivation is the reasons, the impulses that exist in humans that cause him to do something or do something, motivation arises because two factors that influence it, namely intrinsic factors and extrinsic factors. The indicators of teacher work motivation according to Uno (2016: 73) are as follows: 1) internal motivation namely the responsibility of the teacher in carrying out tasks, carrying out tasks with clear targets, having clear and challenging goals, feedback on the results of his work, having feeling happy in work, always trying to outperform others, prioritizing the achievements of what he does; 2) external motivation that is always trying to meet the needs of life and work needs, happy to get praise from what he does, work in the hope of wanting to get incentives, working in the hope of wanting to get the attention of friends and superiors. With the existence of work motivation, it is expected that teachers can be more active and creative in implementing education in schools.

Based on the results of the preliminary survey and several interviews conducted with the principal and teacher of the State Junior High School in Muaro Regency, information was obtained, that the teacher's performance in Muaro Jambi District Junior High School had not been carried out optimally and well. Allegedly this is due to the motivation that is owned and given to each teacher has not been done maximally, the motivation given is different and can change according to the circumstances of each teacher. Some of the problems that arise related to teacher performance are: 1) RPP planning and learning tools that have not been optimally prepared and still copy paste from the internet or from the Ministry of National Education; 2) lack of mastery of material and learning media in conveying material so that it cannot attract students' attention; 3) lack of implementation of maximum learning for students.

Based on the background of the study, it was assumed that the teacher's performance in Muaro Jambi District Junior High School still needed to be improved, in order to achieve maximum quality of teaching staff performance. One of the efforts made to improve teacher performance is to increase the work motivation of teachers in carrying out their work. To be able to know for certain and clearly related to these allegations, the authors are interested in researching the "Effect of Work Motivation on the Performance of Junior High School Teachers in Muaro Jambi District". Through the results of this study is expected to provide solutions to efforts to improve the performance of public junior high school teachers in Muaro Jambi District in the implementation of classroom learning and management for the future. 


\subsection{Work motivation}

The term motivation comes from the Latin verb movere (move). The idea of movement is reflected in common sense ideas about motivation, such as something that makes us begin work on tasks, keep ourselves working on tasks, and help ourselves solve them. Based on this it can be concluded that motivation is a process initiated and maintained activities directed at achieving goals (Schunk, Pintrich \& Meece, 2012: 6).

According to Robbins and Judge (2012: 222) states that motivation is a process that explains the intensity, direction, and perseverance of an individual to achieve his goals. General motivation relates to efforts to achieve any goal.

According to Uno (2016: 71) work motivation is one of the factors that determine a person's performance. The size or effect of motivation on one's performance depends on how much intensity the motivation is given. According to Wursanto (1989: 131-132) states that intrinsic factors are factors within humans which can be: (1) attitude; (2) personality; (3) education; (4) experience; (5) knowledge; and (6) ideals. While extrinsic factors are factors outside the human self can be in the form of: (1) leadership style of a superior; (2) someone's encouragement or guidance; and (3) the development of the situation and so on.

Uno (2016: 73) describes the dimensions and indicators that influence work motivation as follows: 1) internal motivation namely the responsibility of the teacher in carrying out tasks, carrying out tasks with clear targets, having clear and challenging goals, feedback on the results of his work, have a feeling of pleasure in work, always trying to outperform others, prioritizing the achievements of what he does; 2 ) external motivation that is always trying to meet the needs of life and work needs, happy to get praise from what he does, work in the hope of wanting to get incentives, working in the hope of wanting to get the attention of friends and superiors. With the existence of work motivation, it is expected that teachers can be more active and creative in implementing education in schools.

\subsection{Teacher Performance}

According to Ahmadi, R (2010: 1) performance is a popular term in management, in which the term performance is defined by terms of work, work performance and performance.

According Suprihatiningrum (2013: 39) states that teacher performance is the factor that most determines the quality of learning. Thus, improving the quality of education in the quality of teacher performance needs to be given primary attention in policy setting. Performance quality is influenced by several very complex factors and shows whether professional coaching and development in the work unit is successful or failed.

According Supardi (2014: 50) the performance of teachers is strongly influenced by individual characteristics consisting of knowledge, skills, abilities, motivation, beliefs, values, and attitudes. Individual characteristics are strongly influenced by organizational characteristics and job characteristics. According to Uno and Lamatenggo (2014: 70) they argue that teacher performance is several dimensions which include work quality, speed / accuracy, initiative, ability, and communication. These dimensions give birth to the following indicators: 1) the quality of work, the indicators include mastering the material, managing the teaching and learning process, managing the class; 2) speed / accuracy of work, the indicators include using media or learning resources, mastering the foundation of education, planning teaching programs; 3) initiative in work, the indicators include leading the class, managing teaching and learning interactions, assessing learning outcomes; 4) work ability, the indicator includes using various methods in learning, understanding and implementing functions and counseling guidance services; 5) communication, indicators include understanding and administering school administration, and understanding and being able to interpret research results to improve the quality of learning. 


\subsection{Hypothesis}

The hypothesis developed in this study is as follows:

Ho: There is no influence of work motivation on the performance of teachers of state junior high schools in Muaro Jambi Regency.

Ha: There is an effect of work motivation on the performance of teachers of Public Middle Schools in Muaro Jambi Regency

\section{Research Methods}

This study uses descriptive quantitative methods with survey techniques. The population in this study were all public junior high school teachers in Muaro Jambi District totaling 973 teachers, both classroom teachers and subject teachers who were civil servants or non-civil servants. The number of samples in this study was obtained by simple random sampling withdrawal technique, and the level of trust was equal to or higher than .10 .0 .10 with representative intrapolation calculations so that a sample of 150 teachers was obtained.

Data collection techniques in this study used a closed questionnaire / questionnaire with a Likert scale with a large score of positive questions. Validity test in this study uses two methods, namely the validity of the construct carried out by the supervisor and then empirical validity which is then processed using the help of the SPSS version 16.0 for Windows application program. In this study processing the results of the research data was carried out using descriptive statistical analysis techniques, assisted by a simple regression analysis test and the coefficient of determination.

\section{Result and Discussion}

Simple regression analysis is carried out to find out whether work motivation affects teacher performance. From the questionnaire data that has been processed using the help of the SPSS version 16.0 application program

Based on the results table above, it is obtained a constant value in column table B, so that the regression equation can be obtained as follows:

$\mathrm{Y}=\mathrm{a}+\mathrm{bX}$

$\mathrm{Y}=32,418+0,443 \mathrm{X}$

Explanation: teacher's performance level $(\mathrm{Y})=32,418$ (a / constanta) $+0,443$ (work motivation). In order to know whether the regression equation above can be used to predict the size of the criterion variable $(\mathrm{Y})$ based on the predictor $(\mathrm{X})$, a hypothesis test is conducted to determine the significance of the two variables. Hypothesis testing is done using simple linear regression analysis, the following is the result of a simple linear regression analysis using the help of SPSS version 16.0 for windows application program: Based on the results of the ANOVA table above, the results of $F=70,600$ are obtained, with a significance of 0,000 . The Fcount value will be compared with Ftable with dfreg $=1$ and dfresidual $=148$ that is 3.91 at $5 \%$ and 6.81 significance levels at $1 \%$ significance level, to make decisions based on the following test categories:

If Fcount> Ftable then Ho is rejected

If Fcount $<$ Ftable then Ho is accepted

Based on the explanation above, 70,600>3,91 at 5\% significance level and 70,600>6,81 at $1 \%$ significance level, then the decision is obtained that Fcount> Ftable so that Ho is 
rejected. This means that there is a significant influence on work motivation on teacher performance.The coefficient of determination is a test conducted to find and find out how much influence the independent variable $(\mathrm{X})$ on the dependent variable $(\mathrm{Y})$. To find the calculation of the coefficient of determination or R Square (R2) multiplied by $100 \%$, using the help of the SPSS version 16.0 for Windows application program:

Based on the results of the output above, the R Square (R2) value is 0.323 . To find out how much influence work motivation on teacher performance is determined by the following formula:

$\mathrm{KD}=\mathrm{R} 2 \times 100 \%$

$=0.323 \times 100 \%$

$=32.3 \%$

So the conclusion, based on the results of the calculation of the formula above is known that the magnitude of the effect of work motivation on teacher performance is $32.3 \%$. The remaining $100 \%-32.3 \%=67.7 \%$ is influenced by other variables not discussed in this study.

\section{Conclusions}

Based on the calculation and discussion of the results of data processing that is assisted by using the SPSS version 16.0 for window application program, the simple regression analysis shows that there is a significant influence between work motivation on teacher performance. This is indicated by the value of $F=70,600$ with sig.0,000. Based on the results of the comparison at a significance level of $5 \%=3.99$ and $1 \%=7.06$, it shows that Fcount> Ftable is $46.055>3.91$ at a significance level of $5 \%$ and $46.055>6.81$ at a significance level of $1 \%$, meaning the hypothesis zero (Ho) is rejected, so it can be concluded that there is a significant influence on work motivation on teacher performance.

Based on the calculation and discussion of the results of data processing that is assisted by using the SPSS version 16.0 for Windows application program, the analysis of the coefficient of determination (R2) shows that there is an influence between work motivation on teacher performance. This is indicated by the acquisition of the value of $\mathrm{R}$ Square $=0.323$, through the calculation of the formula $\mathrm{KD}=\mathrm{R} 2 \times 100 \%$ that is $\mathrm{KD}=0.323 \times 100 \%$ obtained $32.3 \%$. This means that the magnitude of the effect of work motivation on teacher performance is $32.3 \%$, and the remaining $67.7 \%$ is influenced by other factors not addressed in this study.

\section{Suggestion}

Based on the results of the research and the conclusions, the following suggestions can be given:

1. As an input for public junior high schools in the South Bahar Subdistrict, Muaro Jambi Regency, it is expected that schools can be more active and maximal in providing motivational encouragement both in the form of rewards and proportional reward feedback to the teachers in the school. In order for the teacher's performance in learning and classroom management to be carried out optimally and to contribute positively to the school. As well as increasing the dimensions of work motivation such as; responsible for carrying out tasks, becoming creative educators and able to develop interesting learning and implement classroom management optimally.

2. As a study material for further research, this research only focuses on work motivation as an independent variable. It is expected that the next research can add other factors that are not 
yet in this research, such as work discipline or the leadership of the principal, and so on. And should conduct research that focuses more on indicators of work motivation that have not been discussed in this study. So that the results of this study can really prove an increase in teacher performance.

\section{References}

[1] Ahmadi, R. (2014) Pengantar Pendidikan: Asas dan Filsafat Pendidikan. Pengantar Pendidikan: Asas dan Filsafat Pendidikan. Yogyakarta: Ar. Rozz Media.

[2] Gibson, J, L. (1987) 'Hubungan persepsi guru terhadap kepemimpinan kepala sekolah dan iklim organisasi dengan kinerja guru', Jurnal Tabularasa PPS Unimed, Medan: Universitas Negeri Medan, 8 No.2. Available at: http://digilib.unimed.ac.id.

[3] Robbins, S. P. et al. (2012) Perilaku Organisasi. 12th edn. Jakarta: Salemba Empat.

[4] Schunk, D. H., R, P. P. and I., M. J. (2012) Motivasi dalam Pendidikan: Teori, Penelitian, dan Aplikasinya. Jakarta: Indeks.

[5] Supardi (2014) Kinerja Guru. Jakarta: PT. RajaGrafindo Persada.

[6] Suprihatiningrum, J. (2013) Guru Profesional: Pedoman Kinerja, Kualifikasi, \& Kompetensi Guru. Yogyakarta: Ar-Ruzz Media.

[7] Uno, H. B. and Lamatenggo, N. (2014) Teori Kinerja dan Pengukurannya. Jakarta: Bumi Aksara.

[8] Uno, Hamzah B. (2016) eori Motivasi \& Pengukurannya: Analisis di Bidang Pendidikan. Jakarta: Bumi Aksara.

[9] Usman, H. (2013) Manajemen: Teori, Praktik, dan Riset Pendidikan. Jakarta: Bumi Aksara.

[10] Wursanto (1989) Manajemen Kepegawaian. Yogyakarta: Kanisius. 

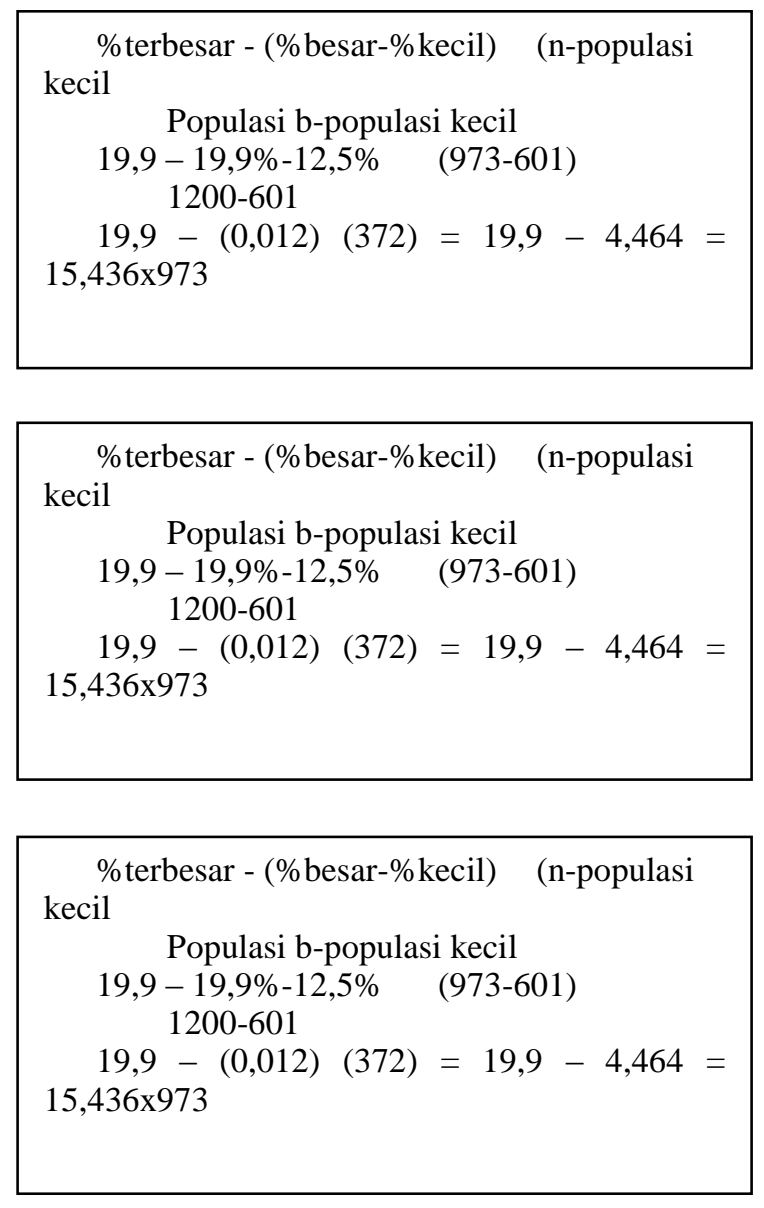

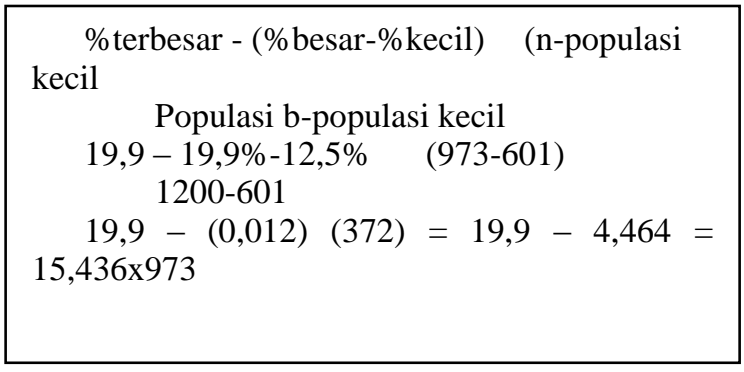

